Commentary

\title{
Return to De Capitani: The EU Legislative Process between Transparency and Effectiveness
}

\author{
Emanuele Rebasti \\ Legal Service, Council of the European Union, 1048 Brussels, Belgium; E-Mail: emanuele.rebasti@consilium.europa.eu
}

Submitted: 5 March 2021 | Accepted: 19 March 2021 | Published: 31 March 2021

\begin{abstract}
Three years after the judgment of the General Court in the De Capitani case, we assess whether the findings of the Court have settled for good the debate between transparency and effectiveness in EU law-making or rather opened new questions on legislative transparency in the EU.
\end{abstract}

\section{Keywords}

4 column tables; De Capitani; decision-making effectiveness; European Union; law-making; legislative transparency; Regulation 1049/2001; trilogues

\section{Issue}

This commentary is part of the issue “Access or Excess? Redefining the Boundaries of Transparency in the EU's DecisionMaking" edited by Camille Kelbel (Lille Catholic University, France), Axel Marx (University of Leuven, Belgium) and Julien Navarro (Lille Catholic University, France).

(C) 2021 by the author; licensee Cogitatio (Lisbon, Portugal). This commentary is licensed under a Creative Commons Attribution 4.0 International License (CC BY).

The landmark judgement of the General Court in the De Capitani (De Capitani v. European Parliament, 2018) has provided an important contribution in redefining the boundaries of transparency in EU law-making. According to most commentators, the General Court has clearly opted for 'access' over 'excess' by giving prominence to transparency over effectiveness when it comes to law-making. Three years after the seminal decision, it is useful to return to De Capitani to assess whether the judgment has really settled for good the debate and excluded the arguments of effectiveness from the functioning of the EU model of representative democracy.

The arguments developed by the parties in the case are a good illustration of the opposing approaches as to the balance to be found between transparency and effectiveness in EU law-making.

In its written submissions, De Capitani had taken the radical view that efficiency is no objective of the legislative procedure. According to De Capitani, in a democratic legislative procedure defined by openness, citizens' participation and public pressure can never be considered as undermining the process. As a consequence, there is no margin left for Institutions to refuse access to a legisla- tive document on the basis of Article 4(3) of Regulation 1049/2001 (Regulation of the European Parliament and of the Council of 30 May 2001, 2001, p.43).

The three Institutions aligned in defending the opposite view that a request for access could still be refused on the basis of the need to protect the efficiency of trilogues as a working method. They did so, however, with some nuances.

The European Parliament developed a rather classic defence which stressed the specific nature of trilogues if compared to the formal steps of the legislative process only, to focus on the risks posed by the disclosure of the specific documents at stake.

The Commission and the Council insisted on a 'functionalist' argument focussing on the need to protect the very function of trilogues, which would be undermined by unfettered openness. The Commission pushed this argument to the extreme on the basis of a case law developed in the framework of ongoing administrative proceedings (see in particular joined cases T-424/11 and T-425/11 in ClientEarth v. European Commission, 2015) and argued for a general presumption that access to the fourth column of documents relating to ongoing 
trilogues would undermine the decision-making process. Such a general presumption would be justified to preserve the integrity of the conduct of the trilogue procedure from the intervention of third parties, in light of the very specific function of tripartite negotiations - that is to explore the possibility of an agreement on a common text between representatives of the co-legislators to be then subject to validation in the official steps of the legislative procedure.

The Council supported the Commission's argument in favour of a general presumption against disclosure. It however further suggested that a distinction should be drawn between formal legislative documents and trilogue documents since they have a mere preparatory character, do not reflect the positions of the legislators and in fact are not even known to them (since it is up to the negotiators to inform back the respective institutions). The higher standard of transparency applicable to formal legislative documents would therefore not be applicable to trilogue tables since the rational for a wider access - namely the need to allow citizens to hold decision-makers into account for their choices-would not apply with the same intensity here.

As it is known, the General Court decided the case in favour of De Capitani. The Court however did not follow the radical approach proposed by the applicant, which would have prevented any refusal to access requests in the framework of legislative proceedings. Such an approach would have manifestly been against the letter of Regulation 1049/2001, which in no way excludes documents relating to legislative procedures from the scope of application of its set of exceptions. The only serious possibility to overcome this unambiguous wording would be to argue the illegality of the relevant provision of the Regulation itself, which however was not attempted by De Capitani, and appears anyhow farfetched in light of the case law of the Court of Justice.

The judgment follows the long-standing case law on legislative transparency which dates back to the Turco (Sweden and Turco v. Council, 2008) and Access Info Europe (Access Info Europe v. Council, 2011) judgments. The principles of publicity and transparency are inherent to the EU legislative process and citizens must be in a position to follow in detail the decision-making process within the institutions to be able to exercise their democratic rights. From that point of view, no distinction can be accepted between the various steps of the legislative process and no relevance can be given to the specific nature of trilogue negotiations.

Still, while rejecting the 'functionalist' approach in the form argued by Council and Commission, the General Court did not dismiss altogether the need to take into account the effectiveness of the legislative process. While generally overlooked by the commentators of the judgment, the relevant passages of the judgement provide important qualifications to the overall findings.

First, the Court confirms its previous Tobacco case law (Herbert Smith Freehils LLP v. Commission, 2016;
Herbert Smith Freehils LLP v. Council, 2016; Philip Morris v. Commission, 2016) and acknowledges that the risk of external pressure can constitute a legitimate ground for restricting access to documents related to the legislative decision-making process. The threshold set by the General Court is admittedly particularly high, since:

The reality of such external pressure must, however, be established with certainty, and evidence must be adduced to show that there is a reasonably and foreseeable risk that the decision...would be substantially affected owing to that external pressure. (De Capitani v. European Parliament, 2018, §99)

In the case of a legislative procedure, this requires to demonstrate that the disclosure of the requested document would lead to "a reaction beyond what could be expected from the public by any member of a legislative body who proposes an amendment to draft legislation" (De Capitani v. European Parliament, 2018, §99).

The General Court seems therefore to suggest that a distinction may be drawn between the form of influence that is normally associated to the public debate on a legislative file and other-more invasive and thus pathological-forms of interference which would warrant the protection of the decision making.

Second, the General Court seems to admit that the legislative process requires a 'space to think' that needs to be protected. Even if trilogues are a substantial part of the legislative procedure, "discussions may take place during (trilogue) meetings for the preparation of the (compromise text) between the various participants, so that the possibility of a free exchange of views is not called into question" (De Capitani v. European Parliament, 2018, §106).

What this passage implies is that while being part of the legislative process, trilogues remain exempted from other requirements that would normally be associated with the formal steps of the legislative process: the pro-active publication of documents, the publicity of the debates, and the need for a fully-fledged linguistic regime of the documents used for deliberations.

These findings show a certain pragmatism of the General Court in striking a balance between the need for transparency which is proper to the legislative process and the need to preserve the effectiveness of the legislative negotiations. The balance consists in applying to trilogue documents the same enhanced standard of transparency when it comes to access to documents requests, while allowing a certain leniency when it comes to the application of the broader publicity regime proper to law-making.

It is the same pragmatism that had led the Ombudsman to acknowledge the positive role of trilogues and to take a clear position in support of the need to protect a certain level of confidentiality during the discussions, position which attracted much criticism by the supporter of transparency at all costs. As the 
Ombudsman had rightly pointed out, without preserving the possibility of a 'space to think' during these inter-institutional exchanges, the core of the negotiations would slide into even more informal formats with greater risks for the transparency of the overall process (European Ombudsman, 2016, see in particular $\S \S 5-6$, 29-31, 68-69).

However, the pragmatism of the General Court has its shortcomings too. The line between the normal reaction that can be expected from the public and pathological interference in the legislative process is one which is difficult to draw. Let aside the extreme cases where pressure on the co-legislators could take the form of a criminal conduct (e.g., corruption of delegates taking parts in trilogues prompted by the disclosure of a document revealing their positions), it remains extremely difficult to determine at which point a legitimate attempt to influence the decision making becomes an undue interference.

The Tobacco case law seems to suggest that a key factor in the assessment is the fact that the document is explicitly requested by someone who has a vested commercial interest in the decision-making process and who intends to use that document to advance such an interest. Many would however argue that lobbying by vested interests is very much part of the public debate around legislation. Moreover, the ingenuity of the applicants in the Tobacco cases-who made clear their identities and the objective they pursued-could easily be avoided by asking for access in anonymous form or as a general member of the public.

Second, and perhaps more importantly, the pragmatism of the General Court reveals a conceptual weakness in the reasoning of the judgment. There is in fact a certain contradiction in proclaiming-without qualification-that trilogues are "a decisive stage in the legislative process" and that "trilogue tables form part of the legislative process" (De Capitani v. European Parliament, 2018, $\S \S 70,75)$ and then accepting that the full regime of publicity usually associated with the legislative debates does not apply to trilogue discussions.

This contradiction is the inevitable consequence of a monolithic conception of the legislative process and of the documents that accompany it. The reality is however more complex. Besides the key official milestones and documents that register the expression of the political will by the co-legislators, many other layers of preparatory activities and documents both by political actors and by support services concur in law-making. All these intermediary steps and preparatory documents cannot be considered as having the same nature and be subject to the same openness regime without grinding to a halt the legislative machinery. For instance, the public interest in disclosure cannot be the same in relation to a document which formally expresses the position of the colegislator and a merely preparatory document reporting the advice of an official to the negotiator (this was indeed the case in Tobacco). Only access to the former is essen- tial to allow public scrutiny on the decision makers and to strengthen the democratic participation of citizens to the decision-making process.

The General Court tells us that in this complex landscape of intermediary steps and preparatory documents, trilogues and four column tables play a peculiar role which warrants a specific regime in terms of openness. The fact of not spelling out the criteria that justify such a regime, leaves however open a number of questions. For instance, having regard to the relevance that the Court gives to the possibility of having a free exchange of views and effective negotiations during trilogues, it would not seem appropriate to apply the same standard of assessment on one hand to documents that report the result of the negotiations and on the other to documents that are tabled before the trilogues and contain compromise proposals to be discussed during those forthcoming negotiations. Even more, the logic of the judgment would seem to exclude that the same regime of openness apply to internal documents that may be drafted for the purpose of forming the institutions' negotiation strategy and identify the area of flexibility and the concessions that could be made during the tripartite negotiations. Disclosure of these internal documents would expose the strategy of the negotiator, create asymmetric negotiating positions and undermine trust, with the effect of compromising the effectiveness of the trilogue setting and shifting the real negotiations in other fora. It would prevent the possibility of that 'free exchange of views' that the General Court does not call into question.

Following the judgement in De Capitani, the institutions have decided not to appeal and have taken steps to implement its findings. Documents reporting the outcomes of trilogues are now systematically identified and as a rule given access to upon request. Trilogues documents are made public by default once the negotiations are closed. However, as the remarks above show, the judgment has not definitively settled the difficult balance between transparency and effectiveness in the various articulations of the legislative process. The many questions left open by the General Court have already emerged in the day-to-day handling of access requests (as shown for instance by a recent confirmatory decision adopted by the Council on 16 February 2021 partially refusing access to documents preparing positions for trilogue negotiations; Council of the European Union, 2021) and anticipate a new episode in the debate on legislative transparency (the European Ombudsman has just launched an inquiry on complaint $360 / 2021 /$ TE brought against the Council's confirmatory decision; European Ombudsman, 2021).

\section{Conflict of Interests}

The author was agent for the Council in the De Capitani case. The views expressed are solely those of the writer and may not be regarded as stating an official position of the Council of the EU. 


\section{References}

Access Info Europe v. Council, Case T-233/09, Judgement of 22 March 2011 (2011).

ClientEarth $v$. European Commission, joined Cases T-424/14 and T-425/15, Judgment of the Court of 13 November 2015 (2015).

Council of the European Union. (2021). Confirmatory decision n. 01/c/01/21 (document number ST 5122/21, adopted on 16 February 2021). Brussels: Council of the European Union.

De Capitani v. European Parliament, Case T-540/15, Judgment of 22 March 2018 (2018).

European Ombudsman. (2016). Decision of the European Ombudsman of 12 July 2016 closing strategic inquiry OI/8/2015/JAS concerning the transparency of Trilogues. Strasbourg: European Ombudsman.

European Ombudsman. (2021). Letter of 26 February 2021 from the European Ombudsman to the Council of the EU on its refusal to provide full public access to documents related to trilogue negotiations on motor vehicle emissions (Complaint 360/2021/TE). Strasbourg: European Ombudsman.

Herbert Smith Freehils LLP v. Council, Case T-710/14, Judgment of the General Court (Eighth Chamber) of 15 September 2016 (2016).

Herbert Smith Freehils LLP v. Commission, Case T-755/14, Judgment of the General Court (Eighth Chamber) of 15 September 2016 (2016).

Philip Morris v Commission, Case T-18/15, Judgment of the General Court (Eighth Chamber) of 15 September 2016 (2016).

Regulation (EC) No 1049/2001 of the European Parliament and of the Council of 30 May 2001 regarding public access to European Parliament, Council and Commission documents. (2001). Official Journal of the European Union, L 145.

Sweden and Turco v. Council, joined cases C-39/05P and C-52/05P, Judgments of 1 July 2008 (2008).

\section{About the Author}

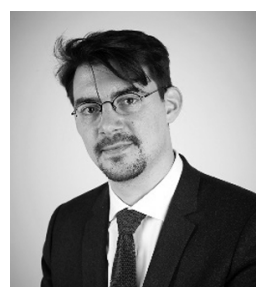

Emanuele Rebasti is Member of the Legal Service of the Council of the European Union, in the Directorate for Economic and Financial Affairs and Budget and previously in the Directorate for Institutional Affairs. 